\title{
Foliar Elemental Analysis of Brazilian Crops via Portable X-ray Fluorescence Spectrometry
}

\author{
Camila S. Borges ${ }^{1}{ }^{1}$, David C. Weindorf ${ }^{2}$, Geila S. Carvalho ${ }^{1}$, Luiz R. G. Guilherme ${ }^{1}$, \\ Thalita Takayama ${ }^{1}$, Nilton Curi ${ }^{1}$, Geraldo J. E. O. Lima ${ }^{3}$ and Bruno T. Ribeiro ${ }^{1,2, *(\mathbb{D}}$ \\ 1 Department of Soil Science, Federal University of Lavras - UFLA, Doutor Sylvio Menicucci Avenue, \\ Lavras 37200-900, Minas Gerais State, Brazil; camila.borges@estudante.ufla.br (C.S.B.); \\ geilacarvalho@ufla.br (G.S.C.); guilherm@ufla.br (L.R.G.G.); thalita.takayama@estudante.ufla.br (T.T.); \\ niltcuri@ufla.br (N.C.) \\ 2 Department of Plant and Soil Science, Texas Tech University, Bayer Plant Science Building, \\ Room 211A, 2911 15th Street, Lubbock, TX 79409-2122, USA; david.weindorf@ttu.edu \\ 3 Campo - Environmental and Technological Agricultural Center, Lindolfo Garcia Adjuto Street, \\ 1000, Paracatu 38600-000, Minas Gerais State, Brazil; geraldo.lima@campoanalises.com.br \\ * Correspondence: bruno.ribeiro@ttu.edu or brunoribeiro@ufla.br
}

Received: 25 March 2020; Accepted: 23 April 2020; Published: 29 April 2020

\begin{abstract}
Foliar analysis is very important for the nutritional management of crops and as a supplemental parameter for soil fertilizer recommendation. The elemental composition of plants is traditionally obtained by laboratory-based methods after acid digestion of ground and sieved leaf samples. This analysis is time-consuming and generates toxic waste. By comparison, portable X-ray fluorescence (pXRF) spectrometry is a promising technology for rapid characterization of plants, eliminating such constraints. This worked aimed to assess the pXRF performance for elemental quantification of leaf samples from important Brazilian crops. For that, 614 samples from 28 plant species were collected across different regions of Brazil. Ground and sieved samples were analyzed after acid digestion (AD), followed by quantification via inductively coupled plasma optical emission spectroscopy (ICP-OES) to determine the concentration of macronutrients (P, K, Ca, Mg, and S) and micronutrients $(\mathrm{Fe}, \mathrm{Zn}, \mathrm{Mn}$, and $\mathrm{Cu}$ ). The same plant nutrients were directly analyzed on ground leaf samples via pXRF. Four certified reference materials (CRMs) for plants were used for quality assurance control. Except for $\mathrm{Mg}$, a very strong correlation was observed between $\mathrm{pXRF}$ and $\mathrm{AD}$ for all plant-nutrients and crops. The relationship between methods was nutrient- and crop-dependent. In particular, eucalyptus displayed optimal correlations for all elements, except for $\mathrm{Mg}$. Opposite to eucalyptus, sugarcane showed the worst correlations for all the evaluated elements, except for $S$, which had a very strong correlation coefficient. Results demonstrate that for many crops, pXRF can reasonably quantify the concentration of macro- and micronutrients on ground and sieved leaf samples. Undoubtedly, this will contribute to enhance crop management strategies concomitant with increasing food quality and food security.
\end{abstract}

Keywords: foliar analysis; plant nutrition; proximal sensors

\section{Introduction}

The nutritional status of crops is crucial for assuring high productivity, food quality, and food security [1,2]. Well-nourished plants are more resilient to pests and diseases [3-5] and to adverse environmental conditions (e.g., dry season, soil water deficiency) [6,7]. At present, Brazil is widely recognized as a global food supplier [8] and for being one of the last agricultural frontiers. According to current world rankings [8,9], Brazil is the number 1 producer of soybean, sugarcane, and coffee; 
the number 2 producer of oilseeds (sunflower seed, peanuts (in shell), cottonseed, and rapeseed); and the number 3 producer of maize. Suitable management of soil fertility and plant mineral nutrition in Brazilian agriculture is one of the main factors responsible for increasing productivity and achieving food security goals in highly weathered-leached soils of Brazil [10].

The technical recommendation of fertilizers is frequently comprised of results from soil fertility analysis [11,12]. Additionally, chemical foliar analysis can be used as a complementary parameter for recommendation of fertilizers $[13,14]$ to confirm observed visual deficiency of a given plant nutrient in the field and for temporal monitoring of the nutritional status of crops $[15,16]$. In sum, soil and foliar analyses are fundamental for successful fertilization and management of crops [17-19].

Foliar analysis of crops has been traditionally performed by wet digestion of oven-dried and ground leaf samples under laboratory conditions [20,21]. This analysis is time and labor consumptive and requires numerous chemicals. In the last two decades, portable X-ray fluorescence (pXRF) spectrometry has been an important and innovative tool in soil science [22,23]. At present, the pXRF method is recognized as an official method for soil analysis [22-26]. In a few seconds, under laboratory conditions or directly in the field, the total elemental composition of soils can be easily and adequately obtained. Furthermore, pXRF methods require no chemicals and are thus environmentally friendly. Based on pXRF spectra, prediction models of many soil properties (e.g., $\mathrm{pH}$, texture, soil organic matter, macroand micronutrients) have been established [27-31]. Several pXRF soil studies have been successfully conducted in tropical environments [32,33].

pXRF approaches can also be used for chemical analysis of plant tissues and seeds [34-36]. However, there is no standard method for this and more investigations are still needed. Some previous works have successfully employed the pXRF to assess the elemental composition of vegetation [37-43]. The concentrations of $\mathrm{Cu}, \mathrm{Zn}, \mathrm{Pb}, \mathrm{K}$, and Fe from different plant species growing in polluted mines were obtained via pXRF and were well correlated to laboratory-based methods [44]. For grasses, a strong correlation between pXRF and acid digestion was obtained for $\mathrm{P}, \mathrm{K}, \mathrm{Ca}$, and Fe [45]. Sulfur, $\mathrm{K}$, and $\mathrm{Ca}$ were reliably measured in cowpea, croton, mango, and maize leaves [40]. However, in Brazil, very few studies using $\mathrm{pXRF}$ for foliar analysis have been performed. The performance of $\mathrm{pXRF}$ was tested for soybean leaves [35] and for some varieties of sugarcane [46].

Given the lack of extensive research on pXRF elemental characterization of Brazilian crops, a study of such seems timely. Thus, the objective of this research was to compare the concentrations of macro$(\mathrm{P}, \mathrm{K}, \mathrm{Ca}, \mathrm{Mg}$, and $\mathrm{S})$ and micronutrients $(\mathrm{Cu}, \mathrm{Fe}, \mathrm{Zn}$, and $\mathrm{Mn}$ ) obtained via $\mathrm{pXRF}$ with those obtained via nitro-perchloric digestion, followed by inductively coupled plasma emission spectroscopy (ICP-OES) quantification. It was hypothesized that the PXRF will accurately quantify plant nutrients, showing strong correlations with conventional acid digestion and lab-based methods. These correlations are expected to be crop-dependent. If suitable correlations are obtained, the pXRF can be proposed as a fast, accurate, and environmentally friendly method for foliar analysis.

\section{Material and Methods}

\subsection{Plant Material Collection from Brazilian Crops}

Diagnostic leaves from 28 plant species were collected in different regions of Brazil (Southern, Southeastern, and Northeast) (Figure 1). The procedures for sampling the diagnostic leaves in the field were specific for each crop (Table S1) [11]. A total of 614 composite leaf samples were collected for this work. Table 1 shows the number of samples for each crop. The samples were sent to an ISO/IEC Standard 17025 Laboratory of Soil and Plant Analysis located in Minas Gerais State, Brazil. In the laboratory, the samples were carefully washed with distilled water, oven-dried $\left(60^{\circ} \mathrm{C}\right)$, and ground $(30 \mathrm{mesh})$. The ground leaf material was stored in cold chamber at $4{ }^{\circ} \mathrm{C}$ for further analysis. 

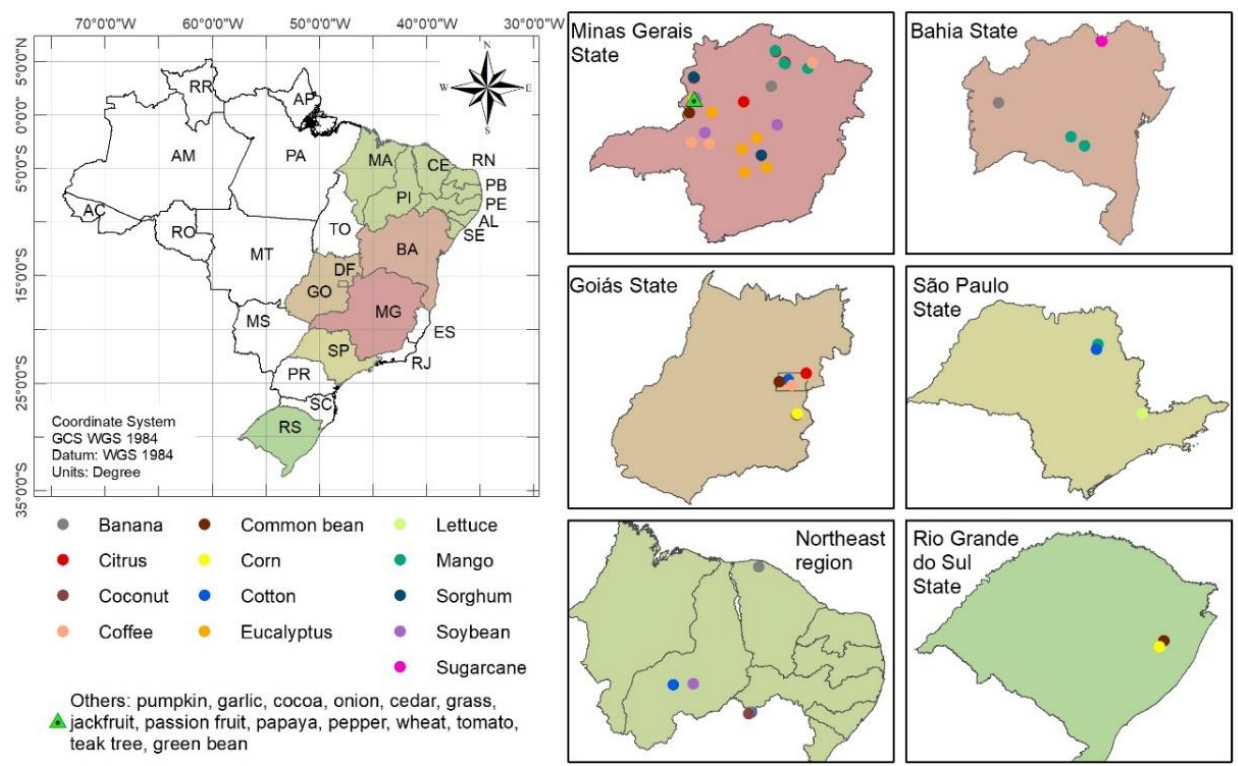

Figure 1. Location of crops in different regions of Brazil selected for this study.

Table 1. Plant species (Brazilian crops) selected for this work.

\begin{tabular}{|c|c|c|}
\hline \multicolumn{3}{|c|}{ Number of Samples (n) } \\
\hline \multicolumn{3}{|c|}{ Cereals and Oilseeds $(\mathrm{n}=157)$} \\
\hline Bean & Phaseolus vulgaris & 45 \\
\hline Corn & Zea mays & 14 \\
\hline Soybean & Glycine max & 11 \\
\hline Sorghum & Sorghum bicolor L. & 24 \\
\hline Wheat & Triticum spp & 1 \\
\hline Cotton & Gossypium hirsutum L. & 62 \\
\hline \multicolumn{3}{|c|}{ Fruits $(n=186)$} \\
\hline Banana & Musa spp. & 96 \\
\hline Coconut & Cocos nucifera L. & 53 \\
\hline Jackfruit & Artocarpus heterophyllus & 1 \\
\hline Mango & Mangifera indica & 26 \\
\hline Passion fruit & Passiflora edulis & 2 \\
\hline Papaya & Carica papaya & 8 \\
\hline \multicolumn{3}{|c|}{ Vegetables $(n=28)$} \\
\hline Garlic & Allium sativum & 2 \\
\hline Green bean & Phaseolus vulgaris L. & 1 \\
\hline Onion & Allium cepa & 2 \\
\hline Tomato & Solanum lycopersicum & 1 \\
\hline Lettuce & Lactuca sativa & 14 \\
\hline Pumpkin & Cucurbita spp & 7 \\
\hline Pepper & Capsicum annuum & 1 \\
\hline \multicolumn{3}{|c|}{ Citrus $(n=46)$} \\
\hline Orange & Citrus sinensisL. Osbeck & 7 \\
\hline Lemon & Citrus limon & 39 \\
\hline \multicolumn{3}{|c|}{ Forest trees $(n=84)$} \\
\hline Cedar & Cedrela fissilis & 5 \\
\hline Eucalyptus & Eucalyptus globulus Labill & 78 \\
\hline Teak trees & Tectona grandis L.f. & 1 \\
\hline \multicolumn{3}{|c|}{ Perennials and semi-perennials $(\mathrm{n}=113$ ) } \\
\hline Coffee & Coffea ssp. & 96 \\
\hline Cocoa & Theobroma cacao & 1 \\
\hline Sugarcane & Saccharum officinarum $L$. & 12 \\
\hline Grass & Poaceae & 4 \\
\hline
\end{tabular}




\subsection{Conventional Analysis of Plant Leaves: Acid Digestion (AD) Method}

For determination of $\mathrm{P}, \mathrm{K}, \mathrm{Ca}, \mathrm{Mg}, \mathrm{S}, \mathrm{Fe}, \mathrm{Cu}, \mathrm{Mn}$, and $\mathrm{Zn}$, the ground samples were wet digested (using the nitro-perchloric acid method) [20,47] with modifications. The samples $(0.5 \mathrm{~g})$ were transferred to $50-\mathrm{mL}$ glass digestion tubes and treated with $6 \mathrm{~mL}$ of acid solution $\left(\mathrm{HNO}_{3}: \mathrm{HClO}_{4}\right.$ 2:1 v/v). Using a heating block digestion system, the samples were digested in three steps: i) heating at $120^{\circ} \mathrm{C}$ for $30 \mathrm{~min}$; ii) heating at $160{ }^{\circ} \mathrm{C}$ for $40 \mathrm{~min}$; and iii) heating at $210^{\circ} \mathrm{C}$ for $20 \mathrm{~min}$. After digestion, the samples were cooled under laboratory conditions to room temperature $\left(22^{\circ} \mathrm{C}\right)$. After cooling, the samples were transferred to $50 \mathrm{~mL}$ volumetric flasks, then brought to volume with ultrapure water. Sub-samples were analyzed using a Ciros Vision ICP-OES (Spectro Analytical Instruments Inc., Kleve, Germany).

\section{3. $p X R F$ Analysis}

Plant nutrients $(\mathrm{P}, \mathrm{K}, \mathrm{Ca}, \mathrm{Mg}, \mathrm{S}, \mathrm{Fe}, \mathrm{Cu}, \mathrm{Mn}$, and $\mathrm{Zn}$ ) were also quantified via pXRF using an Olympus Vanta analyzer (Olympus ${ }^{\circledR}$, Waltham, MA) equipped with a Rh tube (10-40 keV), silicon drift detector, and operated in the Geochem Mode on line power (115 VAC). Homogenized sub-samples of ground plant material were packed into 23-mL plastic vials (48.9 mm high and $27.6 \mathrm{~mm}$ diameter). Inside the plastic vials, at least $1 \mathrm{~cm}$ thickness of plant material was assured for analysis. The vials were covered using Prolene ${ }^{\circledR}$ X-ray thin film (Chemplex Industries Inc., Palm City, FL, USA) and placed on the pXRF aperture. The X-ray thin film was held in place externally by latex rubber (Figure 2). The diameter of plastic vials was sufficient to cover the entire $X$-ray source and detector area without any influence of vial walls. The samples were scanned for $60 \mathrm{~s}$ as follows: beam 1 (first $30 \mathrm{~s}$ ) for Fe, $\mathrm{Cu}$, $\mathrm{Mn}$, and $\mathrm{Zn}$; beam 2 (last $30 \mathrm{~s}$ ) for $\mathrm{P}, \mathrm{K}, \mathrm{Ca}, \mathrm{Mg}$, and $\mathrm{S}$.
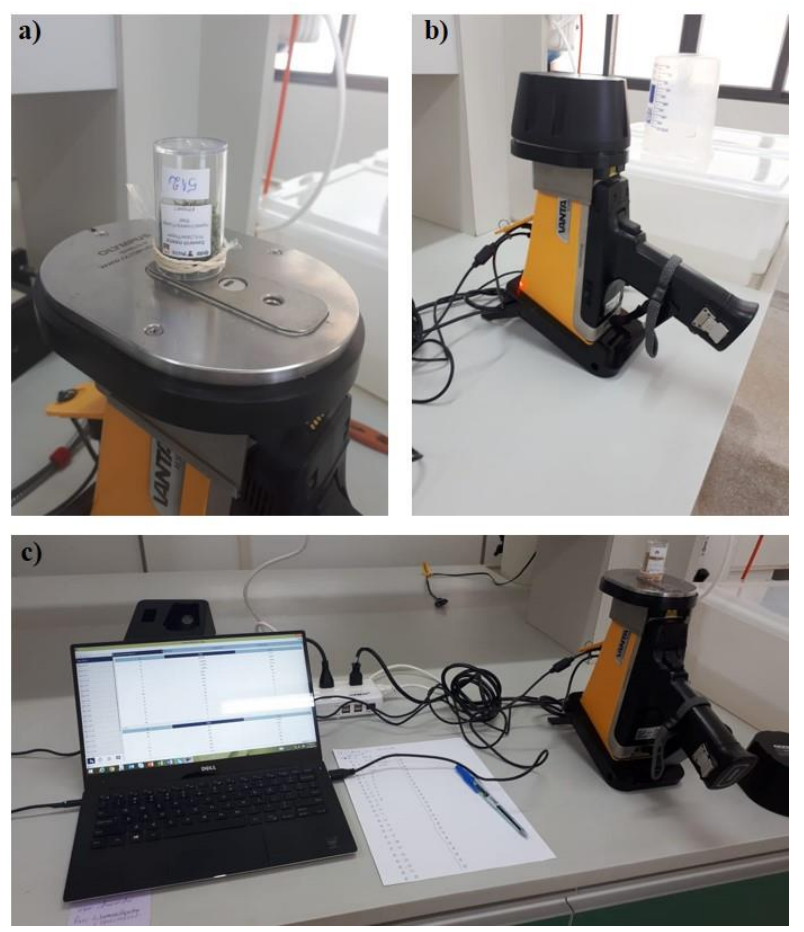

Figure 2. Details of portable X-ray fluorescence (pXRF) measurements. (a) Detail of ground leaf sample into the plastic vial and placed on X-ray source and detector aperture; (b) samples covered by a proper cap for protection against the X-ray; (c) data acquisition in real-time using a laptop connected to pXRF equipment.

For quality assurance and quality control (QA/QC), the following materials were used: Olympus ${ }^{\circledR}$ stainless calibration coin; blank sample (pure $\mathrm{SiO}_{2}$ ) and three certified reference materials (CRMs) from 
the National Institute of Standards and Technology (NIST 1547 peach leaves, NIST 1573a tomato leaves, and NIST 1515 apple leaves). Additionally, an internal standard prepared from soybean leaves was also employed. For each studied element, the recoveries (pXRF value/certified value) were obtained and linear regressions were made. The obtained equations were used as corrections factors (CF) of pXRF measurements. The limits of detection (LOD) considered for low-density sample types were (mg.kg-1): P (50); K (25); Ca (25); Mg (3000); S (50); Mn (5); Fe (5); Cu (5); and Zn (5).

\subsection{Statistical Analyses}

Descriptive statistics (maximum, minimum, median, average, and standard deviation) for the results obtained via both acid digestion (AD) and pXRF were calculated. For comparison between methods, correlations and simple linear regressions were performed for each crop. The crops with fewer than 10 samples (Table 1) were grouped and collectively termed "others" (e.g., vegetables, fruits, etc.).

For the full data set $(n=614), 70 \%$ of data were randomly selected to obtain linear regressions between AD and pXRF for each plant nutrient. The obtained equations were then validated using the remaining $30 \%$ of the data. The statistical significance of correlations and regressions was assessed based on Pearson's correlation coefficient $(R)$, determination coefficient of regression $\left(R^{2}\right)$, root mean square error (RMSE), and mean absolute error (MAE) (Equations (1) to (4), respectively). The linear regression analysis was performed using Sigma Plot Software version 14.0.

$$
R=\frac{\sum_{i=1}^{n} x_{i} y_{i}-\overline{x y}}{\sqrt{\left[\sum_{i=1}^{n} x_{i}^{2}-n \bar{x}^{2}\right]\left[\sum_{i=1}^{n} y_{i}^{2}-n \bar{y}^{2}\right]}}
$$

where $n, \bar{x}$, and $\bar{y}$ indicate the number of samples and the respective mean of each $x_{i}$ and $y_{i}$ variable.

$$
\begin{gathered}
R^{2}=1-\frac{\sum_{i=1}^{n}\left(Y_{i}-\hat{Y}_{i}\right)^{2}}{\sum_{i=1}^{n}\left(Y_{i}-\bar{Y}_{i}\right)^{2}} \\
R M S E=\sqrt{\sum_{i=1}^{n} \frac{\left(\hat{Y}_{i}-Y_{i}\right)^{2}}{n}}
\end{gathered}
$$

where, $Y_{i}, \hat{Y}_{i}$, and $\bar{Y}_{i}$ indicate the observed, the predicted, and the mean of the target variable.

$$
M A E=\frac{\sum_{i=1}^{n}\left|\hat{y}_{i}-y\right|}{n}
$$

where $\mathrm{n}$ indicates the number of samples, and $\hat{y}_{i}$ and $\mathrm{y}$ indicate pXRF and AD measurements, respectively.

\section{Results and Discussion}

\subsection{Recoveries of Elements}

For all elements, pXRF measurements were higher than certified values (Figure 3), supporting previous results [42]. A 1:1 straight correlation was not reached. However, the pXRF results were very reliable, since significant linear regressions between $\mathrm{pXRF}$ measurements and CRM values were obtained with very high $\mathrm{R}^{2}$ values (from 0.96 to 0.99 ) (Figure 3 ). The $\mathrm{pXRF}$ recoveries for each element were almost the same, independent of CRMs. The worst linear regression $\left(R^{2}=0.88\right)$ was obtained for $\mathrm{Mg}$ (Figure 3d), which produces low fluorescence energy and can be influenced by spectral interference. This limitation for $\mathrm{Mg}$ has been reported and its quantification via pXRF should be conducted under vacuum conditions [40]. 

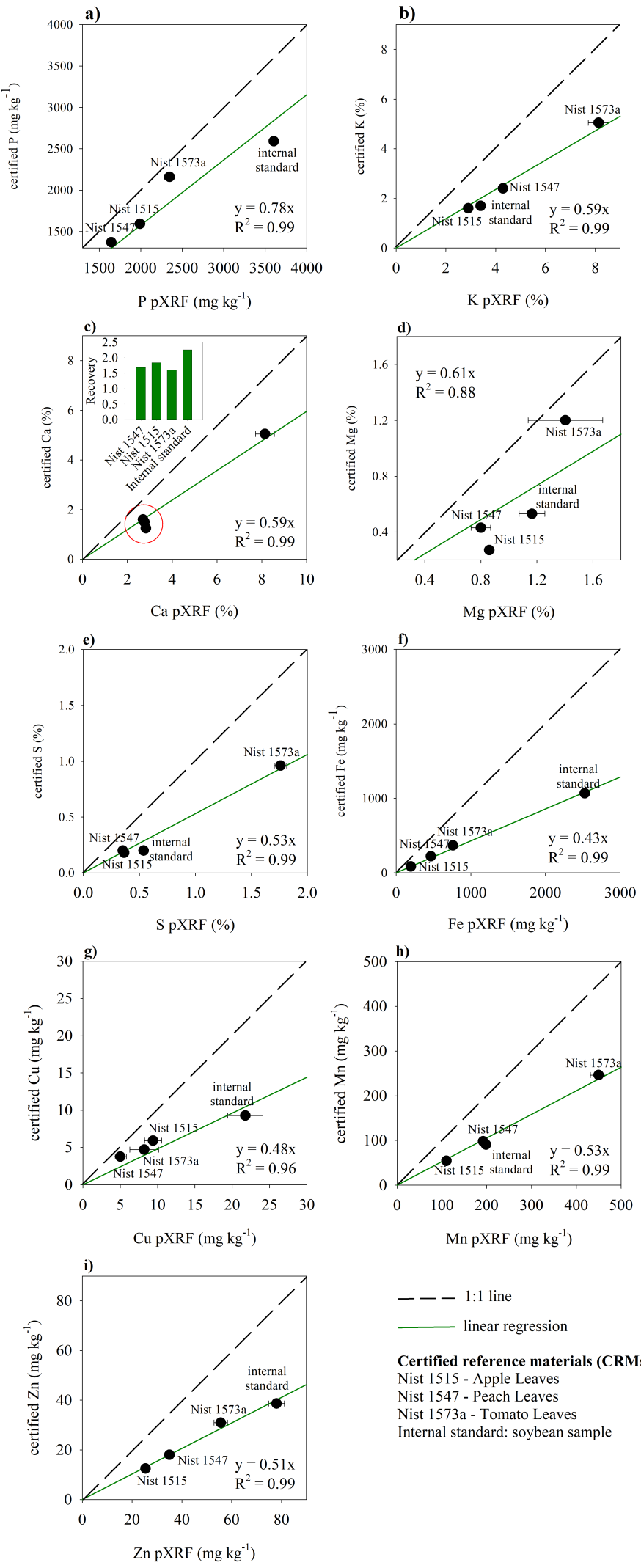

Certified reference materials (CRMs)

Nist 1515 - Apple Leaves

Nist 1547 - Peach Leaves

Nist 1573a - Tomato Leaves

Internal standard: soybean sample

Figure 3. Calibration curve for obtained concentrations via pXRF and certified values for NIST 1515 (apple leaves), NIST 1547 (peach leaves), NIST 1537a (tomato leaves), and an internal standard (soybean sample): (a) Phosphorus; (b) Potassium; (c) Calcium; (d) Magnesium; (e) Sulfur; (f) Iron; (g) Copper; (h) Manganese; (i) Zinc. 
For quality assurance and control, calibration routine on specific matrices can be performed for X-ray fluorescence analysis of plants [48]. Here, a calibration curve was obtained (Figure 3). The b parameter of linear equations $(\mathrm{y}=\mathrm{bx}$ ) (Figure 3) was used as the correction factor (CF) of pXRF measurements. The CF values represent the mean recoveries for four CRMs (NIST 1547; NIST 1573a; NIST 1515; and the internal standard for soybean leaves). For elemental assessment of thatch, deciduous leaves, grasses, tree bark, and herbaceous plants, CF values were considered as a mean of recoveries obtained for NIST 1515 and NIST 1547 [42]. The recovery assessment of CRMs is an important analytical procedure for quality assurance control of analysis [48], allowing a suitable interpretation and discussion of obtained results.

\subsection{General Description of $A D$ and $p X R F$ Data}

For all nutrients, the pXRF measurements were higher than LOD considered for low-density powder samples. The pXRF concentrations were higher than AD (Table 2). These results were expected, since the pXRF reports the total elemental concentration rather than the acid extractable concentration. The performance of $\mathrm{AD}$ methods is influenced by the digestion procedure and dilutions before quantification via ICP-OES [49-51]. Conversely, AD results higher than pXRF were found [35]. However, in Reference [35], they compared the AD method using ground and sieved leaf samples with the PXRF measurements performed directly on fresh leaves. The authors attributed the difference between pXRF and AD to the irregular distribution of nutrients in the leaves. The water content of fresh leaves can also be another factor influencing the results, since the water can attenuate $\mathrm{X}$-rays [52] and underestimates the results [40].

Many factors can influence the plant analysis via X-ray fluorescence techniques [53]. The performance of pXRF is related to particle size distribution, uniformity, homogeneity, thickness, and water content $[40,42,54,55]$. In this work, the pXRF measurements were performed on ground (30 mesh) and sieved samples. A perfect uniformity of plant material size distribution was not expected. However, the size uniformity of plant materials had a minimal effect on chemical analysis via X-ray fluorescence techniques [54].

For all macro- and micronutrients, the mean values were higher than the mean adequate concentrations for plants (MACP) $[55,56]$ (Table 2). Regarding the macronutrients, except for $\mathrm{P}$, the percentage of samples with concentrations higher than the MACP ranged from $81 \%(\mathrm{Ca})$ to $90 \%$ (Mg). For P, only $38 \%$ of samples were higher than the MACP. For the micronutrients, the percentage of samples with concentrations exceeding the MACP ranged from $53 \%$ (Fe) to $67 \%(\mathrm{Zn})$. The most limiting nutrient was $\mathrm{P}$, corroborating the very high P-adsorption capacity of highly-weathered leached soils (e.g., Oxisols) of Brazil [10,57,58], mainly by Fe oxides minerals. The mean concentrations of macronutrients decreased as $\mathrm{K}>\mathrm{Ca}>\mathrm{Mg}>$ $\mathrm{S}=\mathrm{P}$. For the micronutrients, concentrations were observed as $\mathrm{Mn}>\mathrm{Fe}>\mathrm{Zn}>\mathrm{Cu}$. In general, these results corroborate the expected uptake of nutrients by plants $[55,56,59,60]$. Plant mineral nutrition varies between species and from old to young leaves $[55,56]$. It is worthy to mention that in this work standard diagnostic leaves for nutritional status assessment were employed.

After $\mathrm{N}$ (not detectable by pXRF), Ca and $\mathrm{K}$ are the most abundant elements in plant dry matter, with concentrations ranging from 1 to $80 \mathrm{~g} \mathrm{~kg}^{-1}$ [56]. For Ca, both pXRF and AD methods (Table 2) resulted in similar mean values (13.64 and $14.15 \mathrm{~g} \mathrm{~kg}^{-1}$, respectively), and $81 \%$ of samples had Ca concentrations higher than the MACP [55]. The mean $\mathrm{K}$ concentrations varied slightly more between methods (24.20 and $18.12 \mathrm{~g} \mathrm{~kg}^{-1}$ for $\mathrm{pXRF}$ and $\mathrm{AD}$, respectively), but both reported concentrations were considered appropriate. For K, 83\% of samples exceeded the MACP (Table 2). Similar Ca and K concentrations in cowpea, maize, and mango leaves were also obtained via pXRF [40]. Sulfur is the macronutrient found in lower concentrations in plant dry matter, ranging from 1 to $15 \mathrm{~g} \mathrm{~kg}^{-1}$ [56,59]. The obtained results by both AD and pXRF (2.24 and $2.95 \mathrm{~g} \mathrm{~kg}^{-1}$, respectively) support this average concentration. These values were very similar to mean $P$ concentrations $\left(2.46\right.$ and $2.23 \mathrm{~g} \mathrm{~kg}^{-1}$, respectively, for $\mathrm{AD}$ and $\mathrm{pXRF}$ methods), which were below the adequacy level ( 3 to $\left.5 \mathrm{~g} \mathrm{~kg}^{-1}\right)$ [60]. 
High concentrations were observed for $\mathrm{Mn}$, ranging from 21.73 to $4170 \mathrm{mg} \mathrm{kg}^{-1}$ when analyzed via pXRF and from 0.34 to $3273 \mathrm{mg} \mathrm{kg}^{-1}$ when analyzed via AD (Table 2). Adequate concentrations for foliar Mn in plants range from 30 to $500 \mathrm{mg} \mathrm{kg}^{-1}$, with a deficiency from 20 to $30 \mathrm{mg} \mathrm{kg}^{-1}$ and toxicity between 200 and $5300 \mathrm{mg} \mathrm{kg}^{-1}$, depending on the species [61]. The mean and median concentrations obtained for Fe via both AD and pXRF were within the range expected for plants (50 to $250 \mathrm{mg} \mathrm{kg}^{-1}$ ) but values up to $792 \mathrm{mg} \mathrm{kg}^{-1}$ were found via pXRF. Normally, Fe deficiency occurs at concentrations below $50 \mathrm{mg} \mathrm{kg}^{-1}$ [59]. Zinc concentration in plant dry matter is commonly at least five times higher than $\mathrm{Cu}$ [56]. Yet in this work, $\mathrm{Cu}$ concentrations in the leaves were much higher than those of $\mathrm{Zn}$. It is possible that the low levels of $\mathrm{Zn}$ in the leaves are related to the antagonistic effect of $\mathrm{Cu}$, which causes a reduction in $\mathrm{Zn}$ uptake [62]. 
Table 2. Descriptive statistics (minimum, maximum, median, mean, and standard deviation) for pXRF and acid digestion (AD) data.

\begin{tabular}{|c|c|c|c|c|c|c|c|c|c|c|c|c|}
\hline \multirow[t]{2}{*}{ Nutrient } & \multicolumn{2}{|c|}{ Minimum } & \multicolumn{2}{|c|}{ Maximum } & \multicolumn{2}{|c|}{ Median } & \multicolumn{2}{|c|}{ Mean } & \multicolumn{2}{|c|}{ s.d. } & \multirow{2}{*}{ MACP } & \multirow[t]{2}{*}{$\%$} \\
\hline & pXRF & AD & pXRF & AD & pXRF & $\mathrm{AD}$ & pXRF & AD & pXRF & AD & & \\
\hline $\mathrm{P}\left(\mathrm{g} \mathrm{kg}^{-1}\right)$ & 0.52 & 0.32 & 8.99 & 10.96 & 1.67 & 1.64 & 2.46 & 2.23 & 1.75 & 1.71 & 2 & 38 \\
\hline $\mathrm{K}\left(\mathrm{g} \mathrm{kg}^{-1}\right)$ & 2.56 & 0.83 & 91.68 & 49.18 & 21.27 & 17.56 & 24.20 & 18.12 & 15.41 & 9.48 & 10 & 83 \\
\hline $\mathrm{Ca}\left(\mathrm{g} \mathrm{kg}^{-1}\right)$ & 2.08 & 0.48 & 55.49 & 58.74 & 13.96 & 10.80 & 13.64 & 14.15 & 9.94 & 10.96 & 5 & 81 \\
\hline $\operatorname{Mg}\left(\mathrm{g} \mathrm{kg}^{-1}\right)^{* *}$ & 4.34 & 0.79 & 19.34 & 15.09 & 8.36 & 3.89 & 8.62 & 4.30 & 2.35 & 2.34 & 2 & 90 \\
\hline $\mathrm{S}\left(\mathrm{g} \mathrm{kg}^{-1}\right)$ & 0.65 & 0.51 & 14.96 & 15.46 & 2.53 & 1.86 & 2.95 & 2.24 & 1.68 & 1.61 & 1 & 86 \\
\hline $\mathrm{Fe}\left(\mathrm{mg} \mathrm{kg}^{-1}\right)$ & 43.00 & 6.90 & 792.06 & 687.13 & 143.62 & 104.30 & 194.14 & 131.59 & 121.76 & 93.49 & 100 & 53 \\
\hline $\mathrm{Cu}\left(\mathrm{mg} \mathrm{kg}^{-1}\right)$ & 0.00 & 0.18 & 795.84 & 719.40 & 8.16 & 7.39 & 20.76 & 18.03 & 61.55 & 54.53 & 6 & 63 \\
\hline $\operatorname{Mn}\left(\mathrm{mg} \mathrm{kg}^{-1}\right)$ & 21.73 & 0.34 & 4170.04 & 3273.00 & 183.33 & 97.50 & 282.58 & 220.76 & 440.31 & 355.79 & 50 & 61 \\
\hline $\mathrm{Zn}\left(\mathrm{mg} \mathrm{kg}^{-1}\right)$ & 7.65 & 2.38 & 376.89 & 345.58 & 24.48 & 23.79 & 35.25 & 31.32 & 35.70 & 33.32 & 20 & 67 \\
\hline
\end{tabular}

Mean adequate concentration for plant growth (MACP) [55]; ** The pXRF did not detect Mg in $36 \%$ of samples. For Mg, the descriptive statistics represents $64 \%$ of the full data set.

$\%$ : percentage of samples with concentrations higher than MACP. 


\subsection{Correlation between $A D$ and $p X R F$}

The obtained equations from linear regression (70\% of full dataset) between AD and pXRF are shown in Table 3. Considering that AD methods are still a standard method for plant analysis, the AD data were plotted as a function of $\mathrm{pXRF}(\mathrm{AD}=\boldsymbol{a}+\mathrm{pXRF} x$ ). Except for $\mathrm{Mg}$, high $\mathrm{R}$ values were obtained, ranging from $0.81(\mathrm{~K})$ to $0.98(\mathrm{Cu})$. The $\mathrm{R}^{2}$ values ranged from $0.66(\mathrm{~K}, \mathrm{~S}$, and $\mathrm{Fe})$ to $0.97(\mathrm{Cu})$.

Table 3. Linear equations obtained for $70 \%$ of the full dataset correlating to $\mathrm{pXRF}$ and $\mathrm{AD}$ data.

\begin{tabular}{cccc}
\hline Plant-Nutrient & Equation & $\mathbf{R}$ & $\mathbf{R}^{2}$ \\
\hline $\mathrm{P}$ & $\mathrm{AD}=0.80 \mathrm{pXRF}+0.27^{*}$ & 0.84 & 0.70 \\
$\mathrm{~K}$ & $\mathrm{AD}=0.49 \mathrm{pXRF}+6.23^{*}$ & 0.81 & 0.66 \\
$\mathrm{Ca}$ & $\mathrm{AD}=1.01 \mathrm{pXRF}-2.24^{*}$ & 0.92 & 0.84 \\
$\mathrm{Mg}$ & $\mathrm{AD}=0.13 \mathrm{pXRF}+3.26^{\mathrm{ns}}$ & 0.12 & 0.01 \\
$\mathrm{~S}$ & $\mathrm{AD}=0.79 \mathrm{pXRF}-0.08^{*}$ & 0.81 & 0.66 \\
$\mathrm{Cu}$ & $\mathrm{AD}=0.87 \mathrm{pXRF}+0.09^{*}$ & 0.98 & 0.97 \\
$\mathrm{Fe}$ & $\mathrm{AD}=0.63 \mathrm{pXRF}+7.76^{*}$ & 0.82 & 0.66 \\
$\mathrm{Zn}$ & $\mathrm{AD}=0.59 \mathrm{pXRF}+0.52^{*}$ & 0.92 & 0.85 \\
$\mathrm{Mn}$ & $\mathrm{AD}=0.69 \mathrm{pXRF}+18.73^{*}$ & 0.91 & 0.83 \\
\hline \multicolumn{5}{c}{$p<0.01 ;$ non-significant $(\mathrm{ns})}$.
\end{tabular}

The non-significant correlation observed for $\mathrm{Mg}$ is related to the limitations for its determination via XRF techniques, as discussed before [40]. The validation of the obtained equations (Table 3) using $30 \%$ of the data revealed a very accurate prediction for all plant nutrients, with high $\mathrm{R}$ and $\mathrm{R}^{2}$ values (Figure 4). The best prediction was observed for $\mathrm{Cu}\left(\mathrm{R}\right.$ and $\mathrm{R}^{2}=0.99$; $\left.\mathrm{RMSE}=6.47 \mathrm{mg} \mathrm{kg}^{-1}\right)$. Based on $\mathrm{R}$ and $\mathrm{R}^{2}$ values, the accuracy of predictions decreased in the following order: $\mathrm{Cu}>\mathrm{Mn}>\mathrm{Zn}>\mathrm{Ca}>$ $\mathrm{Fe}>\mathrm{P}>\mathrm{K}>\mathrm{S}$.

Except for $\mathrm{Ca}$, the micronutrients (heaviest elements) were better predicted than macronutrients (lightest elements). The ability of the $\mathrm{X}$-ray fluorescence techniques to detect a particular element is directly related to its atomic number $(Z)$ [63]. As the atomic number increases, so does the fluorescence energy. Thus, the so-called light elements (lighter than Ca; e.g., K, P, S, and Mg) are generally weakly identified and quantified via $X$-ray fluorescence techniques, while the heavier elements $(Z>20$, e.g., $\mathrm{Cu}, \mathrm{Zn}, \mathrm{Fe}$, and $\mathrm{Mn}$ ) can be easily measured [22]. For the lightest elements ( $\mathrm{Mg}$, P, and $\mathrm{S}$ ), the best performance of pXRF would be reached under vacuum conditions and without a Prolene ${ }^{\circledR}$ film [40]. Even without specific and intricate vacuum conditions, suitable correlations between AD and pXRF were obtained (Figure 4$)$. A strong correlation was obtained $(R=0.99)$ between $\mathrm{pXRF}$ and AD for $\mathrm{S}$ using pressed pellets of sugarcane leaves [46]. For P, a strong correlation between pXRF data and AD using CRMs for plants was also obtained [64].

The concentration of a given element in the sample can also influence the pXRF performance. For instance, $M n$ and Fe feature similar atomic numbers ( $Z=25$ and $Z=26$, respectively), yet the prediction for Mn was better than Fe. As seen in Table 2, the Mn concentrations were higher than Fe. Similarly, $\mathrm{Zn}$ and $\mathrm{Cu}$ have similar atomic numbers (30 and 29, respectively). Better correlation was observed for $\mathrm{Cu}$, as $\mathrm{Cu}$ concentrations were higher than $\mathrm{Zn}$ (Table 2). The adequate performance observed for Ca can also be related to its high concentration (Table 2). Similarly, a better correlation for $\mathrm{Ca}$ and $\mathrm{K}$ compared to $\mathrm{Mn}$ and Fe was found, where the total concentration within the plant was the compelling factor [65]. 

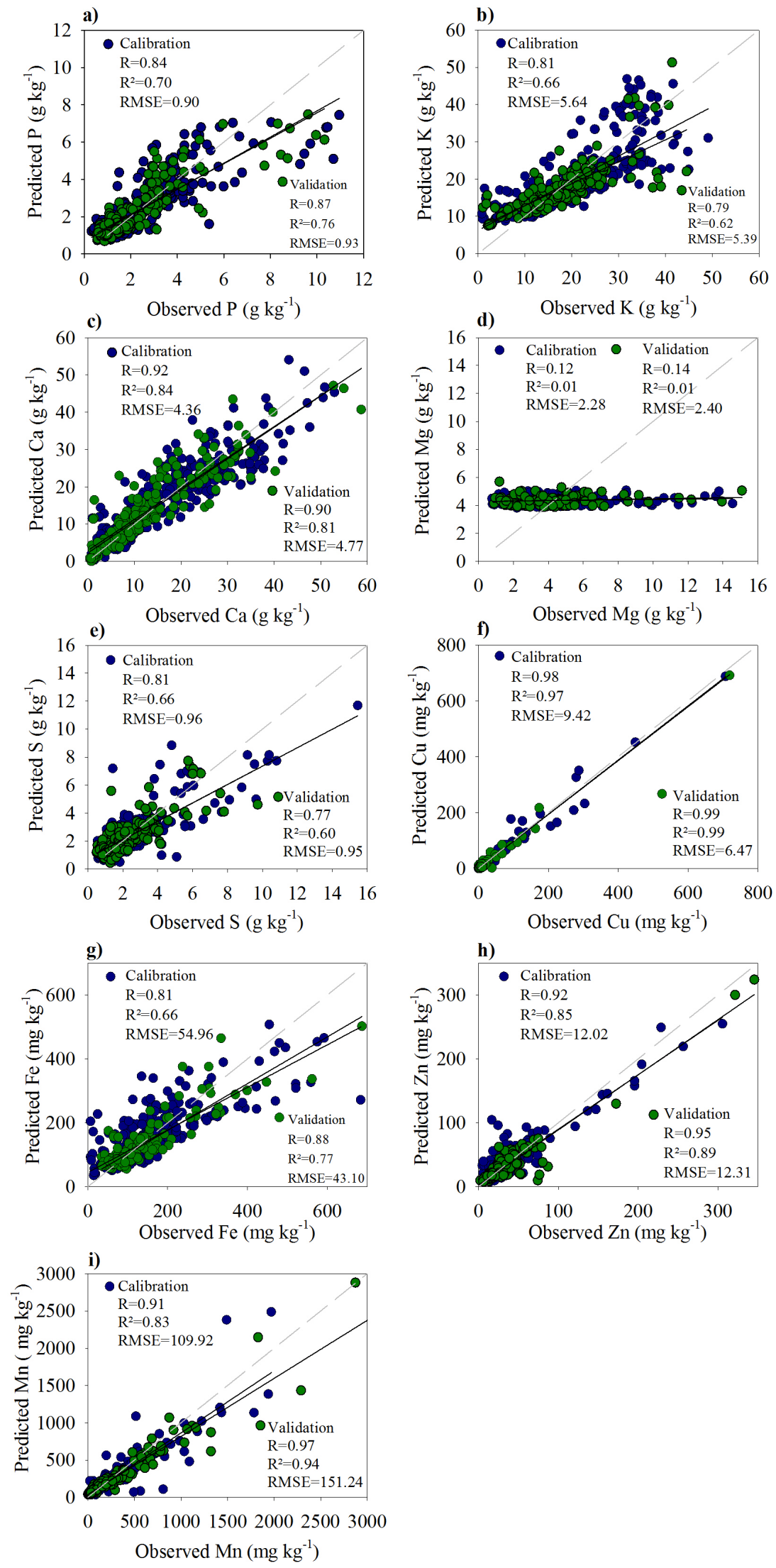

Figure 4. Prediction of macro- and micronutrients concentration in leaf samples from Brazilian crops ( $n=614$ ) using pXRF: (a) Phosphorus; (b) Potassium; (c) Calcium; (d) Magnesium; (e) Sulfur; (f) Copper; (g) Iron; (h) Zinc; (i) Manganese. 


\subsection{Correlation between $p X R F$ and $A D$ for Each Crop}

The correlation between pXRF and AD was nutrient- and crop-dependent (Figure 5). For P (Figure 5a), a very strong correlation between methods was observed for coconut, cotton, lettuce, soybean, and eucalyptus. Sugarcane showed no correlation for P. For K (Figure 5b), a very strong correlation was observed for eucalyptus, cotton, corn, banana, and sorghum and a weak correlation was shown for lettuce. Regarding Ca (Figure 5c), the correlation was strong and very strong for most crops and a weak correlation was also observed for sugarcane. As expected, the worst correlations were observed for $\mathrm{Mg}$ (Figure $5 \mathrm{~d}$ ), where only citrus had a strong correlation. For this nutrient, moderate correlations were observed for banana, soybean, common bean, and lettuce; weak correlations were observed for sorghum and eucalyptus; and no significant correlations were observed for coconut, cotton, and coffee. For S (Figure 5e), contrary to $\mathrm{P}$ and $\mathrm{Ca}$, a very strong correlation was observed for sugarcane and no significant correlations were observed for sorghum and corn.

Regarding the micronutrients, very strong and strong correlations were observed for most crops, mainly for $\mathrm{Fe}, \mathrm{Mn}$, and $\mathrm{Cu}$ (Figure $5 \mathrm{f}-\mathrm{h}$ ). Corroborating the results for $\mathrm{P}$ and $\mathrm{Ca}$, for all micronutrients, the worst correlation was observed in sugarcane. Regarding the macronutrients, the mean absolute errors (MAEs) were quite low (Table 4). The highest MAE values were observed for K (corn, lettuce, sorghum, and sugarcane), ranging from 14.57 to $35.39 \mathrm{mg} \mathrm{kg}^{-1}$ for these crops. For the micronutrients and considering all crops, the mean MAE decreased as Fe $\left(74 \mathrm{mg} \mathrm{kg}^{-1}\right)>\mathrm{Mn}\left(56 \mathrm{mg} \mathrm{kg}^{-1}\right)>\mathrm{Zn}$ $\left(7.4 \mathrm{mg} \mathrm{kg}^{-1}\right)>\mathrm{Cu}\left(5.1 \mathrm{mg} \mathrm{kg}^{-1}\right)$.

Table 4. The mean absolute error (MAE) between pXRF and AD methods for each nutrient and crop.

\begin{tabular}{|c|c|c|c|c|c|c|c|c|c|}
\hline \multirow[t]{2}{*}{ Crop } & $\mathbf{P}$ & $\mathbf{K}$ & $\mathrm{Ca}$ & Mg & 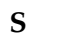 & $\mathrm{Cu}$ & Fe & Zn & Mn \\
\hline & \multicolumn{5}{|c|}{$-\left(\mathrm{g} \mathrm{kg}^{-1}\right)$} & \multicolumn{4}{|c|}{$-\left(\mathrm{mg} \mathrm{kg}^{-1}\right)$} \\
\hline Banana & 0.19 & 6.3 & 0.75 & 4.41 & 0.49 & 1.56 & 41.28 & 1.72 & 106.07 \\
\hline Citrus & 0.24 & 0.24 & 2.94 & 1.55 & 0.01 & 0.37 & 66.22 & 1.58 & 30.39 \\
\hline Coconut & 0.65 & 5.94 & 1.99 & 1.84 & 1.27 & 1.92 & 50.83 & 2.23 & 54.39 \\
\hline Coffee & 0.01 & 4.73 & 4.5 & 3.49 & 0.67 & 5.91 & 44.13 & 3.2 & 48.86 \\
\hline Common bean & 0.45 & 2.68 & 6.45 & 1.71 & 0.74 & 2.98 & 80.16 & 7.72 & 33.7 \\
\hline Corn & 1.29 & 18.41 & 4.61 & * & 2.12 & 7.43 & 102.52 & 23.91 & 52.75 \\
\hline Cotton & 0.37 & 0.51 & 1.43 & 5.73 & 1.02 & 1.45 & 26.89 & 1.64 & 33.08 \\
\hline Eucalyptus & 0.58 & 3.37 & 3.65 & 5.64 & 0.52 & 1.77 & 96.6 & 5.55 & 153.14 \\
\hline Lettuce & 2.16 & 32.59 & 3.63 & 2.49 & 1.82 & 17.37 & 91.2 & 14.24 & 56.18 \\
\hline Mango & 0.33 & 0.76 & 5.19 & * & 0.24 & 4.28 & 31.75 & 1.51 & 40.31 \\
\hline Sorghum & 2.17 & 35.39 & 4.24 & 8.17 & 1.95 & 5.69 & 194.55 & 22.42 & 32.72 \\
\hline Soybean & 0.81 & 3.5 & 6.05 & 0.9 & 0.88 & 15.78 & 99.18 & 10.27 & 55.21 \\
\hline Sugarcane & 0.41 & 14.57 & 2.96 & * & 0.18 & 2.16 & 67.59 & 6.13 & 50.29 \\
\hline Others & 0.42 & 6.85 & 0.7 & 6.39 & 0.45 & 3.34 & 47.64 & 1.14 & 30.79 \\
\hline Mean & 0.72 & 9.70 & 3.51 & 3.85 & 0.88 & 5.14 & 74.32 & 7.38 & 55.56 \\
\hline
\end{tabular}

Citrus: orange and lemon. Others: pumpkin, garlic, cocoa, onion, cedar, grass, jackfruit, passion fruit, papaya, pepper, wheat, tomato, teak tree, and green bean. ${ }^{*}$ For $\mathrm{Mg}$, there was no sufficient data for corn, mango, or sugarcane. 

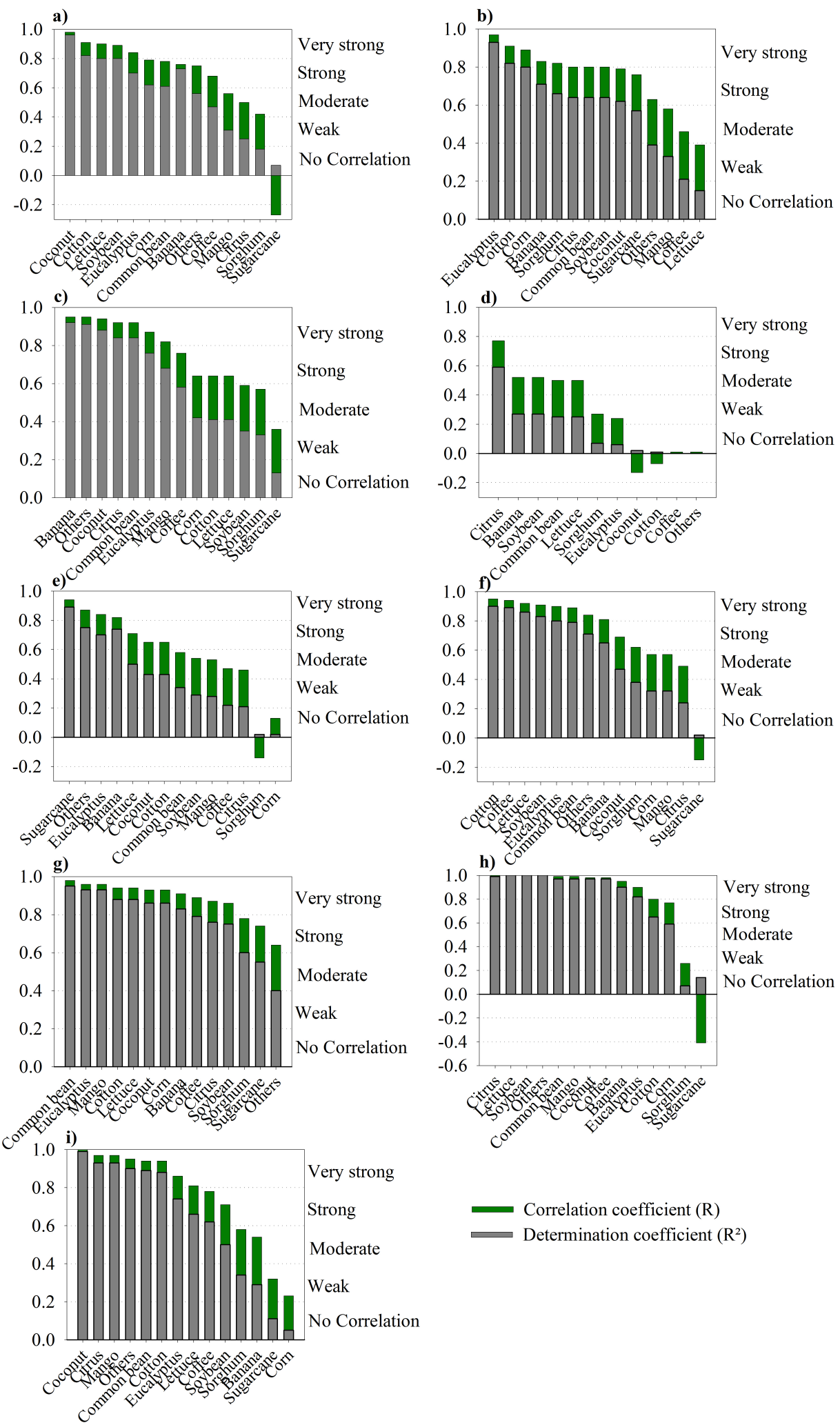

Figure 5. Correlation coefficient $(R)$ and determination coefficient $\left(R^{2}\right)$ from the linear regression between $\mathrm{pXRF}$ and AD methods for each nutrient and crop. Citrus: orange and lemon. Others: pumpkin, garlic, cocoa, onion, cedar, grass, jackfruit, passion fruit, papaya, pepper, wheat, tomato, teak tree, and green bean. For $\mathrm{Mg}$, there was no sufficient data for corn, mango, or sugarcane: (a) Phosphorus; (b) Potassium; (c) Calcium; (d) Magnesium; (e) Sulfur; (f) Iron; (g) Manganese; (h) Copper; (i) Zinc. 
Supporting the results found in this work, a strong correlation between $\mathrm{pXRF}$ and AD was also observed for $\mathrm{Ca}, \mathrm{Mn}, \mathrm{Zn}$, and $\mathrm{Cu}$ in different plant species [44]. Assessing the elemental composition of plants (thatch, deciduous leaves, grasses, tree bark, and herbaceous plants) in mining-impacted areas, a significant correlation for $\mathrm{Cu}, \mathrm{Fe}, \mathrm{Zn}, \mathrm{Mn}, \mathrm{Cd}, \mathrm{Pb}$, and $\mathrm{K}$ was found [42]. Conversely, a poor correlation was observed for $\mathrm{Cu}$ in lettuce plants [41]. The results found that $\mathrm{Ca}, \mathrm{Cu}, \mathrm{Zn}$, and $\mathrm{Mn}$ corroborate the performance of pXRF for soybean, wheat, corn, and cotton samples [37].

Different correlations between methods can be related to the intrinsic characteristics of plant materials, which will determine the performance of $\mathrm{AD}$ procedures [66]. The pXRF performance may be related to the anatomic characteristics of each plant species influencing the X-ray absorption and emission of the fluorescent energy. Further studies involving plant anatomy (e.g., epidermis, adaxial and abaxial surfaces, cuticle, stomata, and mesophyll) are still need to elucidate the diverse performance of pXRF for plant analysis. After that, in-field measurements will be greatly benefited. It is hypothesized here that plant materials with higher cellulose and lignin contents may be more difficult to digest. In general, grasses usually feature higher cellulose and lignin contents [67]. The acid digestion of a lettuce leaf or even the penetration of X-rays may be quite different when compared to more lignified leaves.

The accurate performance of pXRF to assess the elemental composition of plants will greatly contribute to fast and in-field diagnostic of nutritional status, improving the suitable management of soil fertility properties, food quality, and food security. Based on the results of this work, the foliar elemental composition can be analyzed via pXRF on ground and sieved leaf samples, eliminating the need for AD. For in-field applications, further studies are still needed to assess the other factors that can influence the pXRF results, such as water content, anatomy of leaves, cellulose, and lignin contents. Additionally, the nutritional status should be assessed combining pXRF with other proximal sensors (e.g., Vis-NIR, NixPro), as such techniques have been proven to enhance predictive models in coal and soils $[68,69]$. Especially for crops in which foliar fertilization is necessary, the pXRF can be a useful tool for decision-making. The assessment of fruit quality and nutritive value via pXRF is also promising [70] and worthy of additional study.

\section{Conclusions}

Except for Mg, pXRF spectrometry successfully quantified macro- and micronutrients in several leaf samples from important Brazilian crops. For many nutrients, a very strong correlation was observed between pXRF and the most traditional method for foliar analysis (nitro-perchloric digestion). The correlation between pXRF and acid digestion was nutrient- and crop-dependent. Except for Mg, a very strong correlation was always observed for eucalyptus leaves. Conversely, except for $\mathrm{S}$ and $\mathrm{K}$, a weak or non-significant correlation was observed for sugarcane leaves.

Conventional foliar analysis based on acid digestion can be safely replaced by pXRF measurements made directly on ground and sieved leaf samples, dispensing the use of chemicals, acquisition, and maintenance of high-cost equipment (e.g., an atomic absorption spectrometer, an inductively coupled plasma-optical emission spectrometer). Measurements in the field directly on intact and fresh leaves still need more studies to elucidate all factors that can influence the pXRF performance for plant analysis.

Supplementary Materials: The following are available online at http://www.mdpi.com/1424-8220/20/9/2509/s1, Table S1: Sampling details of diagnostic leaves of each crop selected for this study.

Author Contributions: Conceptualization, B.T.R.; methodology, C.S.B, G.S.C., B.T.R., T.T., and D.C.W.; formal analysis, C.S.B. and B.T.R.; investigation, C.S.B. and B.T.R.; resources, B.T.R., G.J.E.O.L., and D.C.W.; data curation, C.S.B. and B.T.R.; writing-original draft preparation, C.S.B., B.T.R., and D.C.W.; writing-review and editing, N.C., L.R.G.G., B.T.R., and D.C.W.; supervision, B.T.R.; project administration, B.T.R.; funding acquisition, B.T.R. and D.C.W. All authors have read and agreed to the published version of the manuscript.

Funding: This project was funded by Minas Gerais Research Foundation (FAPEMIG), grant number APQ-02613-18. B.T.R was funded by the Coordination for the Improvement of Higher Education Personnel (PrInt-Capes) (Process number 888887.363577/2019-00). 
Acknowledgments: The authors gratefully acknowledge the BL Allen Endowment in Pedology at Texas Tech University in conducting this research. Our thanks to the following Brazilian research funding agencies: CNPq, CAPES, and FAPEMIG. We really appreciate the precious help of Maria E.C. Monteiro (PPGCS/UFLA), to create the map of selected crop distribution in Brazil, and CAMPO (Environmental and Technological Agriculture Center) for all their support for conventional foliar analysis.

Conflicts of Interest: The authors declare no conflict of interest. The funders had no role in the design of the study; in the collection, analyses, or interpretation of data; in the writing of the manuscript, or in the decision to publish the results.

\section{References}

1. FAO. Plant Nutrition for Food Security. A Guide for Integrated Nutrient Management; Food and Agriculture Organization of The United Nations (FAO): Rome, Italy, 2006.

2. White, P.J.; Broadley, M.R.; Gregory, P.J. Managing the nutrition of plants and people. Appl. Environ. Soil Sci. 2012, 2012, 104826. [CrossRef]

3. Dordas, C. Role of nutrients in controlling plant diseases in sustainable agriculture: A review. Agron. Sustain. Dev. 2009, 28, 33-46. [CrossRef]

4. Spann, T.M.; Schumann, A.W. The Role of Plant Nutrients in Disease Development with Emphasis on Citrus and Huanglongbing. Proc. Fla. State Hortic Soc. 2009, 122, 169-171.

5. Huber, D.; Römheld, V.; Weinmann, M. Relationship between Nutrition, Plant Diseases and Pests. In Marschner's Mineral Nutrition of Higher Plants, 3rd ed.; Marschner, P., Ed.; Elsevier: London, UK, 2012; pp. 283-298. [CrossRef]

6. Wang, M.; Zheng, Q.; Shen, Q.; Guo, S. The critical role of potassium in plant stress response. Int. J. Mol. Sci. 2013, 14, 7370-7390. [CrossRef] [PubMed]

7. Ahanger, M.A.; Tyagi, S.R.; Wani, M.R.; Ahmad, P. Drought Tolerance: Role of Organic Osmolytes, Growth Regulators, and Mineral Nutrients. In Physiological Mechanisms and Adaptation Strategies in Plants Under Changing Environment; Ahmad, P., Wani, M.R., Eds.; Springer: New York, NY, USA, 2014; Volume 1, pp. $16-43$. [CrossRef]

8. United States Department of Agriculture, Foreing Agricultural Service Home Page. Available online: https://apps.fas.usda.gov/psdonline/circulars/production.pdf (accessed on 20 January 2020).

9. United States Department of Agriculture, Foreing Agricultural Service Home Page. Available online: https://apps.fas.usda.gov/psdonline/circulars/coffee.pdf (accessed on 20 January 2020).

10. Lopes, A.S.; Guilherme, L.G. A career perspective on soil management in the Cerrado region of Brazil. Adv. Agron. 2016, 137, 1-72. [CrossRef]

11. Ribeiro, A.C.; Guimarães, P.T.G.; Alvarez, V.V.H. Recomendação Para o uso de Corretivos e Fertilizantes em Minas Gerais; CFSEMG/UFV: Viçosa, Brazil, 1999. (In Portuguese)

12. Blaylock, A.D.; Belden, K.; Hough, H.W. Guide to Wyoming Fertilizer Recommendations; University of Wyoming: Laramie, WY, USA, 1996.

13. Lucena, J.J. Methods of diagnosis of mineral nutrition of plants a critical review. Acta Hortic. 1997, 448, 179-192. [CrossRef]

14. Cantarutti, R.B.; Barros, N.F.; Martinez, H.E.P.; Novais, R.F. Avaliação da fertilidade do solo e recomendação de fertilizantes. In Fertilidade do Solo; Novais, R.F., Alvarez, V., De Barros, N.F., Fontes, R.L.F., Cantarutti, R.B., Neves, J.C.L., Eds.; Socidade Brasileira de Ciência do Solo: Viçosa, Brazil, 2007; pp. 769-850. (In Portuguese)

15. Munson, R.D. Principles of plant analysis. In Handbook of Reference Methods for Plant Analysis; Kalra, Y.P., Ed.; Taylor \& Francis Group: New York, NY, USA, 1998; pp. 1-24. [CrossRef]

16. Sturgeon, R.E. Current practice and recent developments in analytical methodology for trace element analysis of soils, plants, and water. Commun. Soil Sci. Plant Anal. 2000, 31, 1479-1512. [CrossRef]

17. Elwali, A.M.O.; Gascho, G.J. Soil Testing, Foliar Analysis, and DRIS as Guides for Sugarcane Fertilization. Agron. J. 1984, 76, 466-470. [CrossRef]

18. Creste, J.E.; Echer, F.R. Establishing standards for the integrated recommendation and diagnosis system (DRIS) for irrigated bean crops. Commun. Soil Sci. Plant Anal. 2010, 41, 1921-1933. [CrossRef]

19. Maia, C.E. Fertilization response likelihood for the interpretation of leaf analyses. Rev. Bras. Cienc. Solo 2012, 36, 437-445. [CrossRef] 
20. Miller, R. Nitric-Perchloric Acid Wet Digestion in an Open Vessel. In Handbook of Reference Methods for Plant Analysis; Kalra, Y.P., Ed.; CRC Press: Boca Raton, FL, USA, 1998; pp. 57-61.

21. Isaac, R.A.; Johnson, W.C., Jr. Elemental determination by inductively coupled plasma atomic emission spectroscopy. In Handbook of Reference Methods for Plant Analysis; Kalra, Y.P., Ed.; CRC Press: Boca Raton, FL, USA, 1998; pp. 165-170.

22. Weindorf, D.C.; Bakr, N.; Zhu, Y. Advances in portable X-ray fluorescence (PXRF) for environmental, pedological, and agronomic applications. Adv. Agron. 2014, 128, 1-45. [CrossRef]

23. Ribeiro, B.T.; Silva, S.H.G.; Silva, E.A.; Guilherme, L.R.G. Portable X-ray fluorescence (pXRF) applications in tropical Soil Science. Cienc. Agrotec. 2017, 41, 245-254. [CrossRef]

24. US EPA: Method 6200-Field Portable X-ray Fluorescence Spectrometry for the Determination of Elemental Concentrations in Soil and Sediment. Available online: https://www.epa.gov/sites/production/files/2015-12/ documents/6200.pdf (accessed on 20 January 2020).

25. Soil Survey Staff. Soil Survey Field and Laboratory Methods Manual. Soil Survey Investigations. Available online: https://www.nrcs.usda.gov/Internet/FSE_DOCUMENTS/stelprdb1244466.pdf (accessed on 20 January 2020).

26. Weindorf, D.C.; Chakraborty, S. Portable X-ray Fluorescence Spectrometry Analysis of Soils. In Methods of Soil Analysis; Hirmas, D., Madison, W.I., Eds.; Soil Science Society of America: Madison, WI, USA, 2016; pp. 1-8. [CrossRef]

27. Zhu, Y.; Weindorf, D.C.; Zhang, W. Characterizing soils using a portable X-ray fluorescence spectrometer: 1. Soil texture. Geoderma 2011, 167-168, 167-177. [CrossRef]

28. Sharma, A.; Weindorf, D.C.; Wang, D.D.; Chakraborty, S. Characterizing soils via portable X-ray fluorescence spectrometer: 4. Cation exchange capacity (CEC). Geoderma 2015, 239, 130-134. [CrossRef]

29. de Lima, T.M.; Weindorf, D.C.; Curi, N.; Guilherme, L.R.G.; Lana, R.M.Q.; Ribeiro, B.T. Elemental analysis of Cerrado agricultural soils via portable X-ray fluorescence spectrometry: Inferences for soil fertility assessment. Geoderma 2019, 353, 264-272. [CrossRef]

30. Andrade, R.; Faria, W.M.; Silva, S.H.G.; Chakraborty, S.; Weindorf, D.C.; Mesquita, L.F.; Guilherme, L.R.G.; Curi, N. Prediction of soil fertility via portable X-ray fluorescence (pXRF) spectrometry and soil texture in the Brazilian Coastal Plains. Geoderma 2020, 357, 113960. [CrossRef]

31. Andrade, R.; Silva, S.H.G.; Weindorf, D.C.; Chakraborty, S.; Faria, W.M.; Mesquita, L.F.; Guilherme, L.R.G.; Curi, N. Assessing models for prediction of some soil chemical properties from portable X-ray fluorescence (pXRF) spectrometry data in Brazilian Coastal Plains. Geoderma 2020, 357, 113957. [CrossRef]

32. Silva, F.M.; Weindorf, D.C.; Silva, S.H.G.; Silva, E.A.; Ribeiro, B.T.; Guilherme, L.R.G.; Curi, N. Tropical Soil Toposequence Characterization via pXRF Spectrometry. Pedology 2019, 83. [CrossRef]

33. dos Santos Teixeira, A.F.; Pelegrino, M.H.P.; Faria, W.M.; Silva, S.H.G.; Gonçalves, M.G.M.; Acerbi, F.W., Jr.; Gomide, L.R.; Pádua, A.L., Jr.; de Souza, I.A.; Chakraborty, S.; et al. Tropical soil pH and sorption complex prediction via portable X-ray fluorescence spectrometry. Geoderma 2020, 361, 114132. [CrossRef]

34. Bachiega, P.; de Almeida, E.; Salgado, J.M.; Arruda, M.A.Z.; Lehmann, E.L.; Morzelle, M.C.; de Carvalho, H.W.P. Benchtop and Handheld Energy-Dispersive X-Ray Fluorescence (EDXRF) as Alternative for Selenium Concentration Measurement in Biofortified Broccoli Seedling. Food Anal. Method. 2019, 12, 1520-1527. [CrossRef]

35. Costa, G.T., Jr.; Nunes, L.C.; Gomes, M.H.F.; de Almeida, E.; de Carvalho, H.W.P. Direct determination of mineral nutrients in soybean leaves under vivo conditions by portable X-ray fluorescence spectroscopy. X-ray Spectrom. 2019, 49, 1-10. [CrossRef]

36. Melquiades, F.L.; Bortoleto, G.G.; Marchiori, L.F.S.; Bueno, M.I.M.S. Direct determination of sugar cane quality parameters by X-ray spectrometry and multivariate analysis. J. Agric. Food Chem 2012, 60, 10755-10761. [CrossRef] [PubMed]

37. McLaren, T.I.; Guppy, C.N.; Tighe, M.K. A Rapid and Nondestructive Plant Nutrient Analysis using Portable X-Ray Fluorescence. Soil Sci. Soc. Am. J. 2012, 76, 1446-1453. [CrossRef]

38. Paltridge, N.G.; Milham, P.J.; Ortiz-Monasterio, J.I.; Velu, G.; Yasmin, Z.; Palmer, L.J.; Guild, G.E.; Stangoulis, J.C.R. Energy-dispersive $X$-ray fluorescence spectrometry as a tool for zinc, iron and selenium analysis in whole grain wheat. Plant Soil. 2012, 361, 261-269. [CrossRef]

39. Paltridge, N.G.; Palmer, L.J.; Milham, P.J.; Guild, G.E.; Stangoulis, J.C.R. Energy-dispersive X-ray fluorescence analysis of zinc and iron concentration in rice and pearl millet grain. Plant Soil. 2012, 361, 251-260. [CrossRef] 
40. Towett, E.K.; Shepherd, K.D.; Drake, B.L. Plant elemental composition and portable X-ray fluorescence (pXRF) spectroscopy: Quantification under different analytical parameters. X-ray Spectrom. 2016, 45, 117-124. [CrossRef]

41. Sacristán, D.; Viscarra Rossel, R.A.; Recatalá, L. Proximal sensing of Cu in soil and lettuce using portable X-ray fluorescence spectrometry. Geoderma 2016, 265, 6-11. [CrossRef]

42. McGladdery, C.; Weindorf, D.C.; Chakraborty, S.; Li, B.; Paulette, L.; Podar, D.; Pearson, D.; Kusi, N.Y.O.; Duda, B. Elemental assessment of vegetation via portable X-ray fluorescence (PXRF) spectrometry. J. Environ. Manag. 2018, 210, 210-225. [CrossRef]

43. Montanha, G.S.; Rodrigues, E.S.; Marques, J.P.R.; Almeida, E.; Reis, A.R.; Carvalho, H.W.P. X-ray fluorescence spectroscopy (XRF) applied to plant science: Challenges towards in vivo analysis of plants. Metallomics 2019, 12, 183-192. [CrossRef]

44. Gutiérrez-Ginés, M.J.; Pastor, J.; Hernández, A.J. Assessment of field portable X-ray fluorescence spectrometry for the in situ determination of heavy metals in soils and plants. Environ. Sci. Proc. Imp. 2013, 15, 1545-1552. [CrossRef]

45. Sapkota, Y.; McDonald, L.M.; Griggs, T.C.; Basden, T.J.; Drake, B.L. Portable X-Ray fluorescence spectroscopy for rapid and cost-effective determination of elemental composition of ground forage. Front. Plant Sci. 2019, 10, 1-9. [CrossRef] [PubMed]

46. Guerra, M.B.B.; de Almeida, E.; Carvalho, G.G.A.; Souza, P.F.; Nunes, L.C.; Santos, D., Jr.; Krug, F.J. Comparison of analytical performance of benchtop and handheld energy dispersive X-ray fluorescence systems for the direct analysis of plant materials. J. Anal. Atom. Spectrom. 2014, 29, 1667-1674. [CrossRef]

47. Malavolta, E.; Vitti, G.C.; Oliveira, S.A. Avaliação do Estado Nutricional das Plantas: Princípios e Aplicações, 2nd ed.; Associação Brasileira para pesquisa da Potassa e do Fosfato: Piracicaba, Brazil, 1997. (In Portuguese)

48. Byers, H.L.; McHenry, L.J.; Grundl, T.J. XRF techniques to quantify heavy metals in vegetables at low detection limits. Food Chem. 2019, 1, 100001. [CrossRef]

49. Lavilla, I.; Filgueiras, A.V.; Bendicho, C. Comparison of digestion methods for determination of trace and minor metals in plant samples. J. Agric. Food Chem. 1999, 47, 5072-5077. [CrossRef]

50. Carneiro, C.; Reissmann, C.B.; Marques, R. Comparação de métodos de análise química de $\mathrm{K}, \mathrm{Ca}, \mathrm{Mg}$ e Al, em folhas de erva-mate (Ilex paraguariensis St. Hil.). Cerne 2006, 12, 113-122.

51. Bernardi, A.C.C.; Oka, S.H.; de Souza, G.B. Comparação de técnicas analíticas para a extração de potássio de amostras de tecido vegetal com água e soluções ácidas concentrada e diluída. Eclet. Quim. 2010, 35, 45-49. [CrossRef]

52. Kalnicky, D.J.; Singhvi, R. Field portable XRF analysis of environmental samples. J. Hazard. Mater. 2001, 83, 93-122. [CrossRef]

53. Marguí, E.; Queralt, I.; Hidalgo, M. Application of X-ray fluorescence spectrometry to determination and quantitation of metals in vegetal material. TrAC Trend. Anal. Chem. 2009, 28, 362-372. [CrossRef]

54. Omote, J.; Kohno, H.; Toda, K. X-Ray fluorescence analysis utilizing the fundamental parameter method for the determination of the elemental composition in plant samples. Anal. Chim. Acta 1995, 307, 117-126. [CrossRef]

55. Kirkby, E. Introduction, Definition and Classification of Nutrients. In Marschner's Mineral Nutrition of Higher Plants; Marschner, P., Ed.; Elsevier: London, UK, 2012; pp. 3-14. [CrossRef]

56. Epstein, E.; Bloom, A.J. Mineral Nutrition of Plants: Principles and Perspectives, 2nd ed.; Sinauer Associates Publishers: Sunderland, MA, USA, 2005.

57. Rodrigues, M.; Pavinato, P.S.; Withers, P.J.A.; Teles, A.P.B.; Herrera, W.F.B. Legacy phosphorus and no tillage agriculture in tropical oxisols of the Brazilian savanna. Sci. Total Environ. 2016, 542, 1050-1061. [CrossRef]

58. Roy, E.D.; Willig, E.; Richards, P.D.; Martinelli, L.A.; Vazquez, F.F.; Pegorini, L.; Spera, S.A.; Porder, S. Soil phosphorus sorption capacity after three decades of intensive fertilization in Mato Grosso, Brazil. Agric. Ecosyst. Environ. 2017, 249, 206-214. [CrossRef]

59. Broadley, M.; Brown, P.; Cakmak, I.; Rengel, Z.; Zhao, F. Function of Nutrients: Micronutrients. In Marschner's Mineral Nutrition of Higher Plants; Marschner, P., Ed.; Elsevier: London, UK, 2012; pp. 191-248. [CrossRef]

60. Hawkesford, M.; Horst, W.; Kichey, T.; Lambers, H.; Schjoerring, J.; Møller, I.S.; White, P. Functions of Macronutrients. In Marschner's Mineral Nutrition of Higher Plants; Marschner, P., Ed.; Elsevier: London, UK, 2012; pp. 135-189. [CrossRef] 
61. Clarkson, D.T. The Uptake and Translocation of Manganese by Plant Roots. In Manganese in Soils and Plants; Graham, R.D., Hannam, R.J., Uren, N.C., Eds.; Springer: Dordrecht, The Netherlands, 1988; pp. 101-111. [CrossRef]

62. de Varennes, A.; Carneiro, J.P.; Goss, M.J. Characterization of manganese toxicity in two species of annual medics. J. Plant Nutr. 2001, 24, 1947-1955. [CrossRef]

63. Gates, W.P. Chapter 12.3 X-ray Absorption Spectroscopy. In Handbook of Clay Science; Bergaya, F., Theng, B.K.G., Lagaly, G., Eds.; Elsevier: London, UK, 2006; pp. 789-864. [CrossRef]

64. Reidinger, S.; Ramsey, M.H.; Hartley, S.E. Rapid and accurate analyses of silicon and phosphorus in plants using a portable X-ray fluorescence spectrometer. New Phytol. 2012, 195, 699-706. [CrossRef] [PubMed]

65. Tighe, M.; Forster, N. Rapid, Nondestructive Elemental Analysis of Tree and Shrub Litter. Commun. Soil Sci. Plant Anal. 2014, 45, 53-60. [CrossRef]

66. Melo, L.C.A.; Silva, C.A. Influência de métodos de digestão e massa de amostra na recuperação de nutrientes em resíduos orgânicos. Quim. Nova 2008, 31, 556-561. [CrossRef]

67. de Carvalho, A.M.; Dantas, R.D.A.; Coelho, M.C.; Lima, W.M.; Souza, J.P.S.P.; Fonseca, O.P.; Guimarães, R., Jr. Teores de Hemiceluloses, Celulose e Lignina em Plantas de Cobertura com Potencial para Sistema Plantio Direto no Cerrado; Embrapa Cerrados: Planaltina, Brazil, 2010; pp. 1-15.

68. Kagiliery, J.; Chakraborty, S.; Acree, A.; Weindorf, D.C.; Brevik, E.C.; Jelinski, N.A.; Li, B.; Jordan, C. Rapid quantification of lignite sulfur content: Combining optical and X-ray approaches. Int. J. Coal Geol. 2019, 216, 103336. [CrossRef]

69. Weindorf, D.C.; Chakraborty, S.; Herrero, J.; Li, B.; Castañeda, C.; Choudhury, A. Simultaneous assessment of key properties of arid soil by combined PXRF and Vis-NIR data. Eur. J. Soil Sci. 2016, 67, 173-183. [CrossRef]

70. Kalcsits, L.A. Non-destructive measurement of calcium and potassium in apple and pear using handheld X-ray fluorescence. Front. Plant Sci. 2016, 7, 1-8. [CrossRef]

(C) 2020 by the authors. Licensee MDPI, Basel, Switzerland. This article is an open access article distributed under the terms and conditions of the Creative Commons Attribution (CC BY) license (http://creativecommons.org/licenses/by/4.0/). 